\title{
ANATOMICAL STUDY OF CORNUS MAS L. AND CORNUS OFFICINALIS SEIB. ET ZUCC. (CORNACEAE) ENDOCARPS DURING THEIR DEVELOPMENT
}

\author{
Maria MorozowsKa, Ilona WysaKowsKa
}

\begin{abstract}
M. Morozowska, I. Wysakowska, Department of Botany, Poznań University of Life Sciences, Wojska Polskiego 71 C, 60-625 Poznań, Poland, e-mail: mariamor@up.poznan.pl, ilwys@up.poznan.pl
\end{abstract}

(Received: June 17, 2015. Accepted: October 20, 2015)

\begin{abstract}
AвSTRACt. Results of anatomical studies on the developing endocarps of Cornus mas and C. officinalis are presented. Formation of an endocarp and anatomical changes in its structure from the flowering stage to fully developed fruits were observed with the use of LM and SEM. In the process of anatomical development of endocarps the formation of two layers, i.e. the inner and the outer endocarp, was observed. Changes in their anatomical structure consisted in a gradual thickening of cell walls and their lignification. The lignification of endocarp cell walls begins in the inner endocarp, it proceeds in the outside parts of the outer endocarp, with an exception of several layers of cells forming the transition zone (circular strand) present on its margin, and finally, almost at the same time, in the rest of the outer endocarp. Cell walls of the cells distinguishing the germinating valves undergo thickening delayed by several days in comparison to other endocarp cells. Thickening of their cell walls starts in cells situated close to the inner endocarp and proceeds to its outer parts, and their lignification is not very intensive. The described scheme of the development and lignification of C. mas and C. officinalis endocarps is similar to that of Prunus cerasus (Rosaceae).
\end{abstract}

KEY WORDS: dogwoods, fruit, anatomy, endocarp, lignification

\section{INTRODUCTION}

The genus Cornus L. (Cornaceae) comprises approximately 58 tree and shrub species found mainly in the northern hemisphere in the temperate zone, rarely found in tropical Africa and South America (WANGERin 1910, Macbride 1929, Eyde 1988, Seneta \& DolaTOWSKI 2009, STEVENS 2012).

In Poland only two wild species have been reported, i.e. dwarf cornel (Cornus suecica L.), at present assigned the extinct species status (ŻUKOWSKI \& JАCKOWIAK 1995), and common dogwood (Cornus sanguinea L.) (BugazA 2000). Many other species are grown and planted as ornamentals in gardens and parks (MIREK et al. 2002, RutKowsкi 2006). These species include e.g. Cornus mas L. (cornelian cherry) and Cornus officinalis Seib. et Zucc. (Asiatic dogwood or Japanese cornel dogwood). Decorative value of these species is connected with their early flowering, closely following that of the common hazel and preceding forsythia. At that time numerous tiny yellow-coloured flowers develop before leaves appear. Next in the late summer and autumn decorative bright-red fruits mature. Cornus mas fruits thanks to the high contents of ascorbic acid and flavonoids are known for the high health-promoting value, particularly antioxidant activity (PAWLOWSKA et al. 2010). In Turkey they are used for their antiallergenic, antihistaminic and bactericidal properties (ERCISLI et al. 2011). Vitamin C content in fruit of this species is very high, over $100 \mathrm{mg} / 100 \mathrm{~g}$ fruit, which is a value higher than that in other fruits rich in that vitamin (VIDRIH et al. 2012). Moreover, its fruits also contain high levels of polyphenols and anthocyanins (PANTELIDIS et al. 2007). Stones of cornelian cherry fruits may be used as a raw material to produce oil rich in unsaturated fatty acids (KuCHARSKA et al. 2009). Fruits of $C$. mas are also useful raw material, which may be processed to various products (DEmIR \& KaLYONCU 2003). In turn, fruits of C. officinalis are used in traditional Chinese medicine to treat kidney disease and diabetic nephropathy. Studies have also shown a positive effect of glycosides isolated from Cornus fruits against nephropathy. Loganin and its 
derivatives proved to be particularly effective in this respect (Wei MA et al. 2014).

Both above-mentioned Cornus species investigated in this study belong to the group of 'cornelian cherries' (CC) comprising six species (Cornus sessilis Torr. ex Durand, C. mas L., C. officinalis Sieb. et Zucc, C. chinensis Wangerin, C. volkensii Harms, and C. eydeana Q.Y. Xiang et Y.M. Shui). 'Cornelian cherries' constitute one of four major clades, into which Cornus species are divided in the current phylogenetic classification (XIANG et al. 1993, 1996, 1998, 2006, FAN \& XIANG 2001).

Detailed studies on the development and anatomical structure of the pericarp conducted to date concerned plants producing stone fruits from the family Rosaceae (Tukey \& Young 1939, Kaniewski 1963), as well as selected species from the genus Rosa L. (ZiELIŃSKi et al. 2010, GuZicKA et al. 2012). Moreover, studies on the formation of the pericarp in several selected species from the genus Cornus were also carried out by Kaniewski \& Hausbrandt (1968). In relation to the genus Cornus a recent study described and presented a comparative analysis along with an analysis of genetic variation of the anatomical structure of mature fruits in C. mas and C. officinalis as well as their apparent hybrid (MorozowskA et al. 2013). Results of the above mentioned studies indicate different types of endocarp development in stone fruits. The thickening process followed by cell wall lignification in the endocarp, despite certain regularities, progresses differently in individual species. It varies not only in terms of the site, at which it is initiated, but also the direction, in which it develops within the endocarp.

The aim of the presented study was to follow endocarp development in C. mas and C. officinalis from the moment of fruit setting to their full maturity, taking into consideration the progressing process of thickening and lignification of cell walls in the fruit endocarp. Identification of individual stages in endocarp development will show whether and if so, following which of the patterns of drupe formation described to date, endocarps develop in the analysed species.

\section{MATERIAL AND METHODS}

Analyses were conducted on two species from the genus Cornus: C. officinalis and C. mas. Material for investigations comprised fruits varying in their maturity, which were collected from plants growing under comparable conditions at the Botanical Garden of the Adam Mickiewicz University in Poznan and at the Arboretum in Kórnik, in western Poland (Table 1). Plant material was sampled throughout the entire vegetation season in 2011, from the flowering phase to full fruit maturity, initially at 7-day and next at 14-day intervals. The successive stages in endocarp development had to be analysed on different stones, which had been growing under varied weather conditions, thus the total fruit formation time could only be roughly estimated. After harvest the experimental material was preserved and stored in FAA $(70 \%$ ethanol $90 \%$, acetic acid $5 \%$, formalin $5 \%$ ).

In order to conduct an analysis of the anatomical structure transverse sections (at three stone length levels: at the base, at mid-section and under the stone apex) and longitudinal sections were prepared both manually and using a Leitz sliding microtome. In order to detect lignified cell walls microtome slices of $50 \mu \mathrm{m}$ in thickness were treated with floroglucinol with hydrochloric acid. Stained slides were examined under a light microscope (LM) and images of selected specimens were taken using an OptaView camera.

Endocarp sections for observations under a scanning electron microscope (SEM) were prepared manually, dehydrated in an acetone series at concentrations of $30 \%, 50 \%, 70 \%, 90 \%$, and $100 \%$, three times for 6 min each and sputtered with gold. Observations were conducted at the Laboratory of Electron and Confocal Microscope, AMU in Poznań, under a Zeiss EVO 40 scanning electron microscope at 8-15 $\mathrm{kV}$ depending on the species.

Since fully developed stones of dogwood fruits are very hard, preparation of transverse sections turned out to be impossible at their full maturity, i.e. after reaching full colouring.

Table 1. Location and provenance of analysed species

\begin{tabular}{cccl}
\hline \multicolumn{1}{c}{ Species } & Symbol of plant collection & Plant number in plant collection & \multicolumn{1}{c}{ Origin } \\
\hline Cornus mas & AMU BGP & 191 & no data \\
& AMU BGP & 1519 & planted before 1951 \\
& AMU BGP & 7227 & The Bolestraszyce Arboretum, Poland \\
& KA & 49 & planted before 1926 \\
Cornus officinalis & KA & 6956 & Kyoto Botanical Garden, Japan \\
& AMU BGP & 04987 & Dresden, Germany \\
\hline
\end{tabular}

Explanation:

AMU BGP - Adam Mickiewicz University Botanical Garden in Poznań,

KA - The Kórnik Arboretum. 


\section{RESULTS AND DISCUSSION}

Analysed plants from both Cornus species differed slightly in the phenology of flowering and fruiting, which may result from their genetic variation and local weather conditions during the vegetation period. However, the period of fruit formation from flowering to the development of mature fruits and their complete colouring lasted for approximately 140 days. When analysing individual fruit development stages it was found that $C$. mas was slightly more advanced in development in relation to C. officinalis. Anthesis was observed in both investigated species with a time lag of 2-3 days, respectively.

Studies conducted to date on the development of drupes show that it comprises three stages. Stage I is the phase of rapid growth, taking place after anthesis. At that time we observe both a rapid increase in the number of cells and their size. Cell walls gradually thicken, but are not yet lignified. In stage II, the so-called period of delayed growth, the process of stone hardening progresses, as cell walls continue to thicken and lignify. Stage III is the so-called second stage of rapid growth, lasting until fruit maturity. It consists mainly in the growth of the mesocarp, while stone hardness increases slightly (KANIEWSKI 1963).

The cyclic fruit development was presented for the first time by Connors (1919) based on the peach. A little later the next development stages were described by TukeY (1935), who established three development stages for cherry fruits (Prunus cerasus L.). Next Tukey \& Young (1939) confirmed the above-mentioned results in further studies on Prunus cerasus L. var. Montmorency. Changes in the anatomical development of fruits in Prunus domestica L. were described in detail by STERLING (1953), in Rubus strigosus Michx. by Reeve (1954a, b), while in Rubus occidentalis L. by BOYNTON \& WILDE (1959), thus confirming the three-stage scheme for pericarp development. A slightly different process - comprising two stages, also as a result of a different fruit type, is observed for the development of the pericarp in different species from the genus Rosa (ZIELIŃsKI et al. 2010, GuzicKA et al. 2012).

Conducted morphological observations combined with length measurements of the forming fruits in the examined dogwoods confirmed that at the initial stage of pericarp formation, i.e. within the first 35 and the following 28 days after flowering (up to 10.05.11 and 7.06.11, respectively), the greatest increase in fruit length was recorded. In relation to the length values from the first observations it was $118.7 \%$ and $153.5 \%$ for C. mas and $95.9 \%$ and $106.0 \%$ for C. officinalis, respectively. At later dates this increase was no longer as significant, ranging from several to less than twenty percent of the previous value. In the next interval covering the period between days 63 and 91 after flowering (7.06-5.07.2011), major anatomical changes were taking place within the stone, consisting in the increase in the thickness of cell walls and their lignification, i.e. transformation into sclereids. In the above-mentioned period changes in fruit size, including their length, were not as marked. Throughout July the process of fruit maturation was progressing, during which their colour was changing and the fruits were becoming increasingly fleshy. In relation to anatomical structure the above-mentioned processes were connected mainly with the growth of the mesocarp. According to the results given by KANIEWSKi \& HausbrandT (1968), the growth of the fleshy pericarp in C. mas lasts until the end of July.

Based on the observations of transverse and longitudinal sections of mature fruits in C. mas and C. officinalis as well as the existing literature data (KANIEWSKi \& HausbrandT 1968, MorozowsKa et al. 2013) it may be stated that the anatomical structure in the fully developed pericarp is similar in both analysed species. It is composed of three layers: the exocarp, mesocarp and endocarp. The exocarp is typically composed of a single layer of tiny cells with strongly thickened outer cells, while the mesocarp is made up of one - two layers of hypodermal cells and several layers of relatively large isodiametric thin-walled parenchyma cells. The endocarp (the stone) is formed by cells with thick, lignified walls. In the endocarp we may distinguish two layers, the outer and the inner endocarp, which differ in terms of the shape of cells and their orientation (MorozowsKa et al. 2013).

In the first stage of the so-called rapid fruit growth in C. mas and C. officinalis, i.e. in the initial development stages lasting from 22.03.2011 to 26.04.2011, no differences were observed either in transverse or longitudinal sections in terms of the thickness of cell walls within the entire endocarp. Cells forming individual layers were of similar size and shape, although a subtle difference may already be observed in the size of cells forming the mesocarp and the endocarp. These observations concerned both examined species (Figs 1 and 2). After the next two weeks (10.05.2011) cells were still thin-walled, while a boundary between the meso- and endocarp was clearly marked based on the difference in the size of cells forming these two pericarp layers and the manner of their arrangement. Cells forming the mesocarp were larger, rounded and arranged much more loosely in comparison to the polygonal, closely arranged endocarp cells (Fig. 3). Moreover, according to KaniewsKi \& HAUSBRANDT (1968) the inner part of the forming pericarp, i.e. the future endocarp, was devoid of chloroplasts, in contrast to the outer part, particularly cells located closer to the epidermis. In the forming endocarp bands of smaller cells with a relatively looser arrangement, delineating the outline of the germination valve, could be distinguished (Fig. 4). Resin cavities, much larger than the surrounding cells, could also be seen (Fig. 5). The manner of formation, distribution and size of 
Maria Morozowska, Ilona Wysakowska
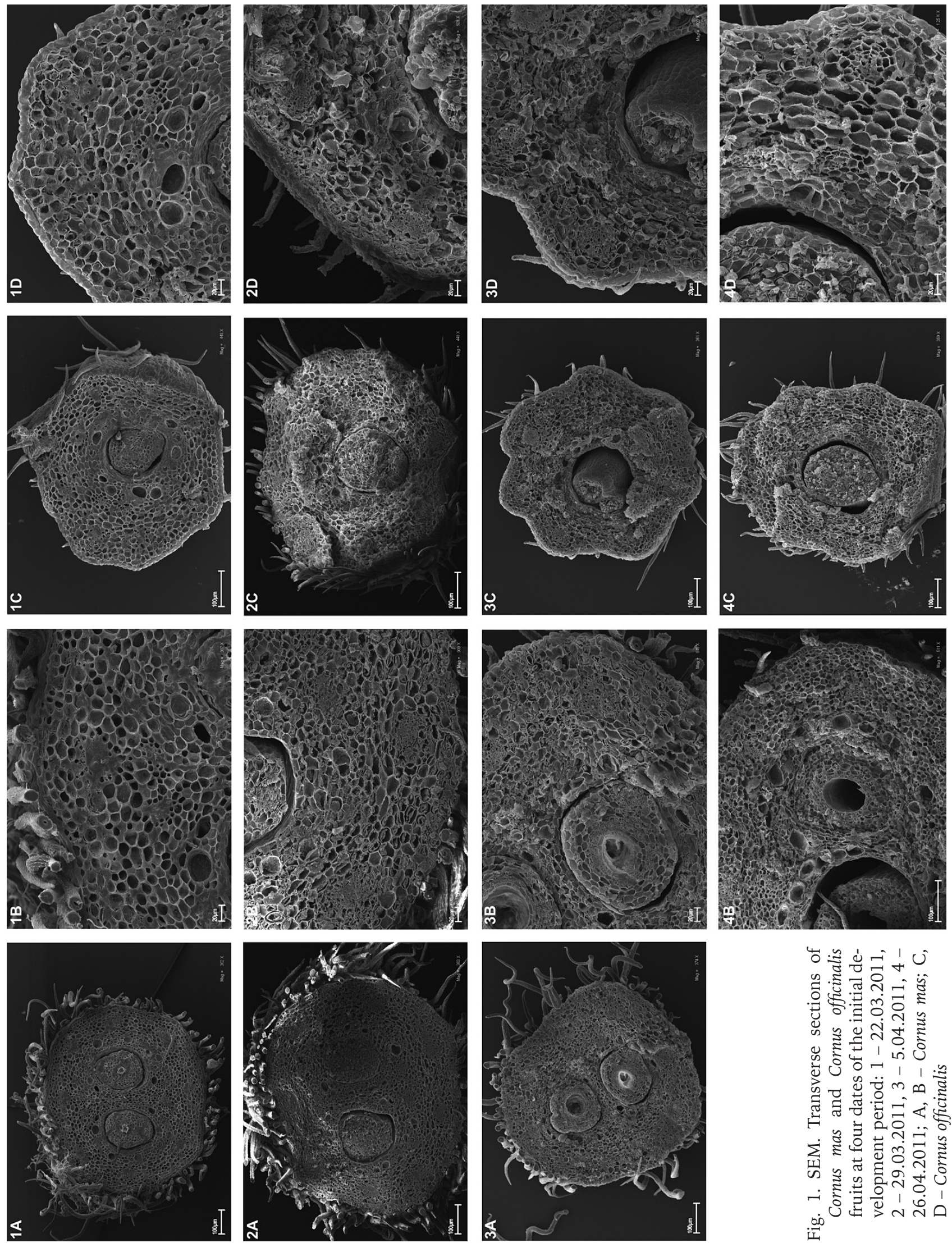

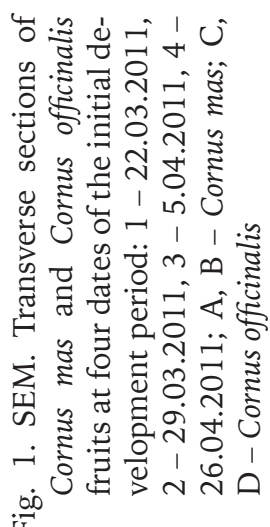



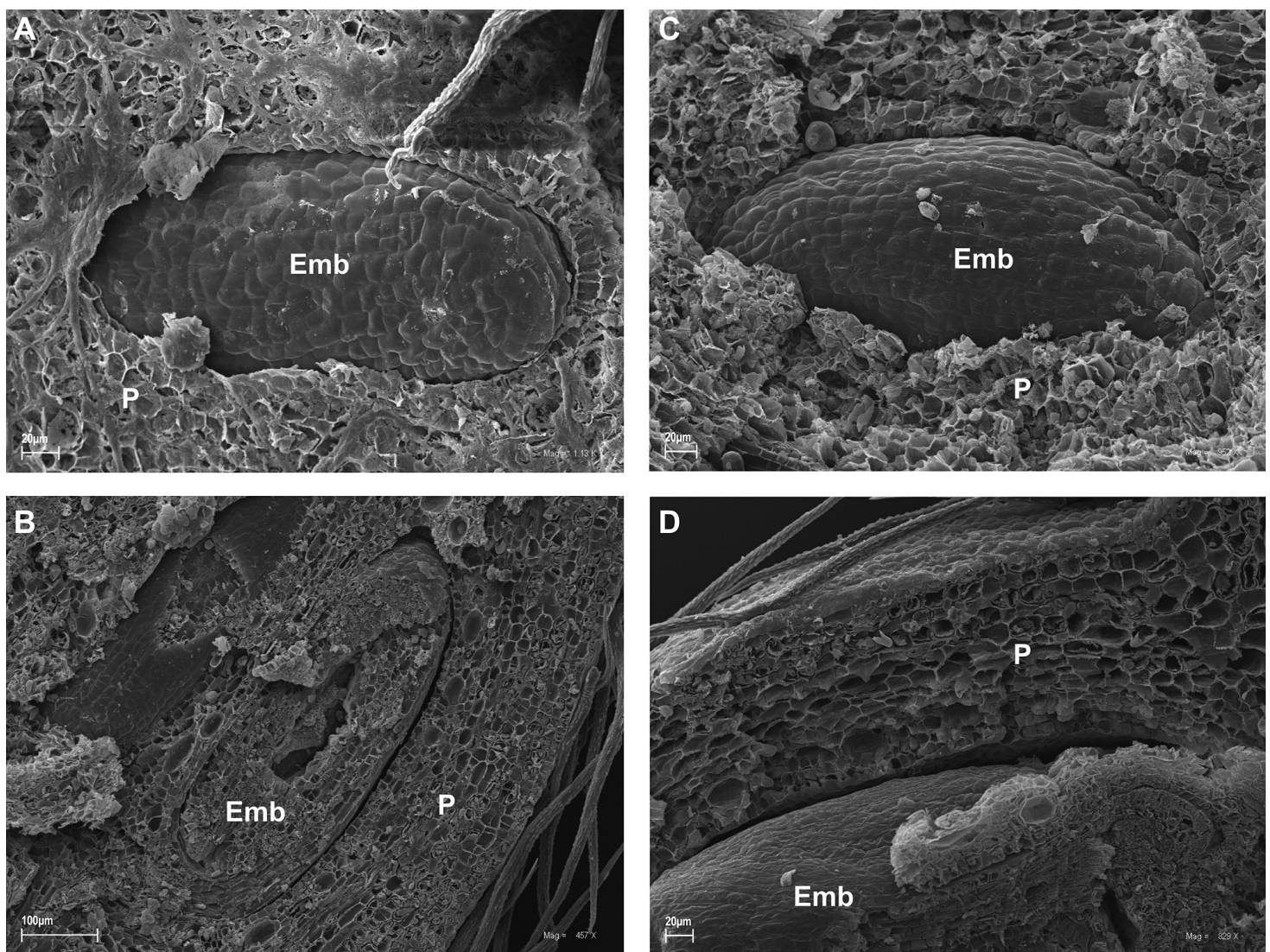

Fig. 2. SEM. Longitudinal sections Cornus mas and Cornus officinalis of fruit in the initial development period: A, B - Cornus mas, C, D - Cornus officinalis, Emb - embryo, P - pericarp
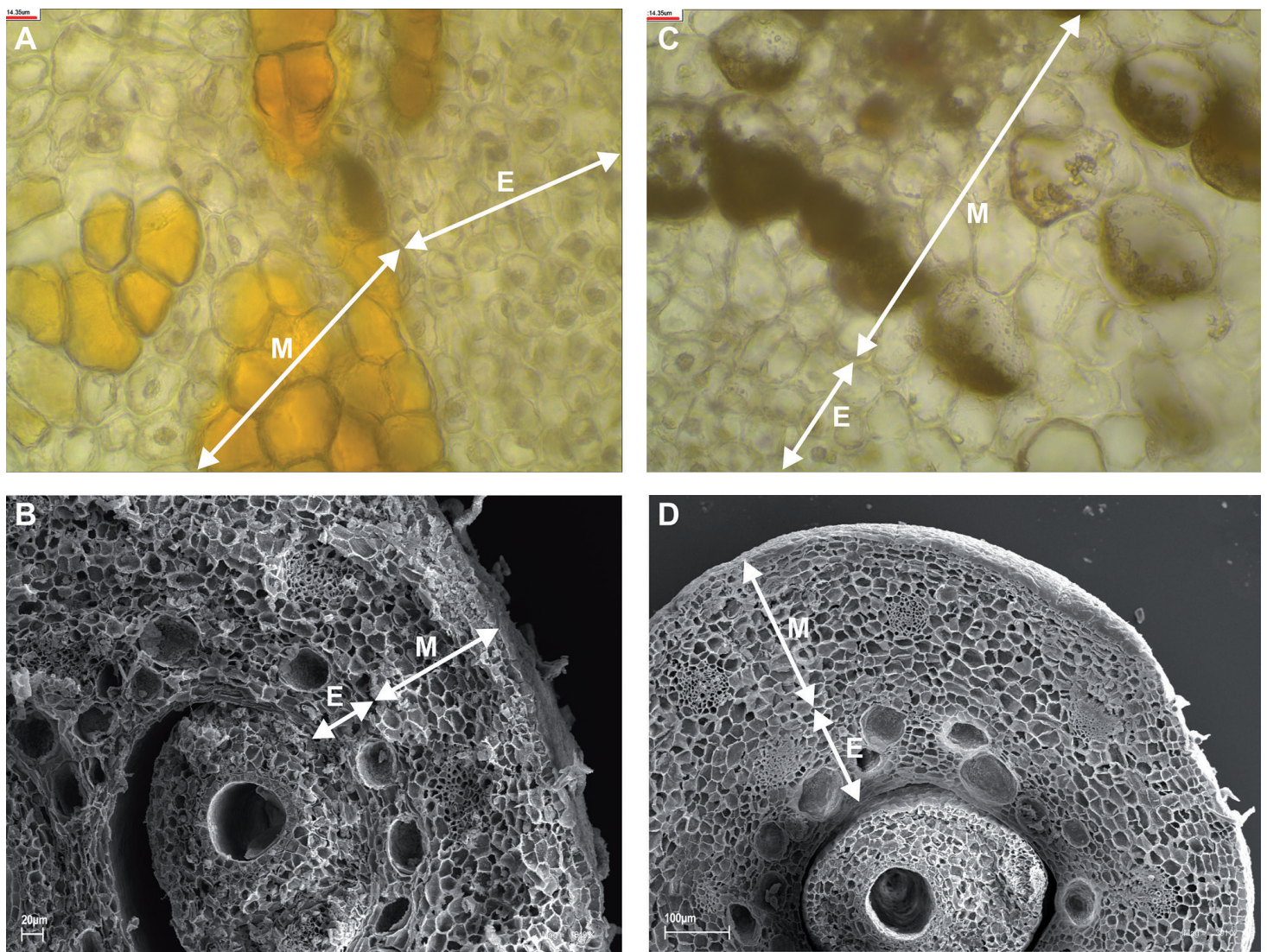

Fig. 3. Variation in size and shape of mesocarp and endocarp cells in Cornus mas and Cornus officinalis: A - Cornus mas (LM), B - Cornus mas (SEM), C - Cornus officinalis (LM), D - Cornus officinalis (SEM); M - mesocarp, E - endocarp 
secretory cells in Cornus mas were described by KANIEWSKI \& HAUSBRANDT (1968).

During the next two weeks (up to 24.05.2011), i.e. also during the 1st phase of fruit growth, anatomical changes in the endocarp were still difficult to observe in SEM; however, combined observations in SEM and LM confirmed rather evident differences between cells forming the outer and inner endocarp. The inner endocarp was made up of several layers of transversely elongated sclereids arranged parallel to
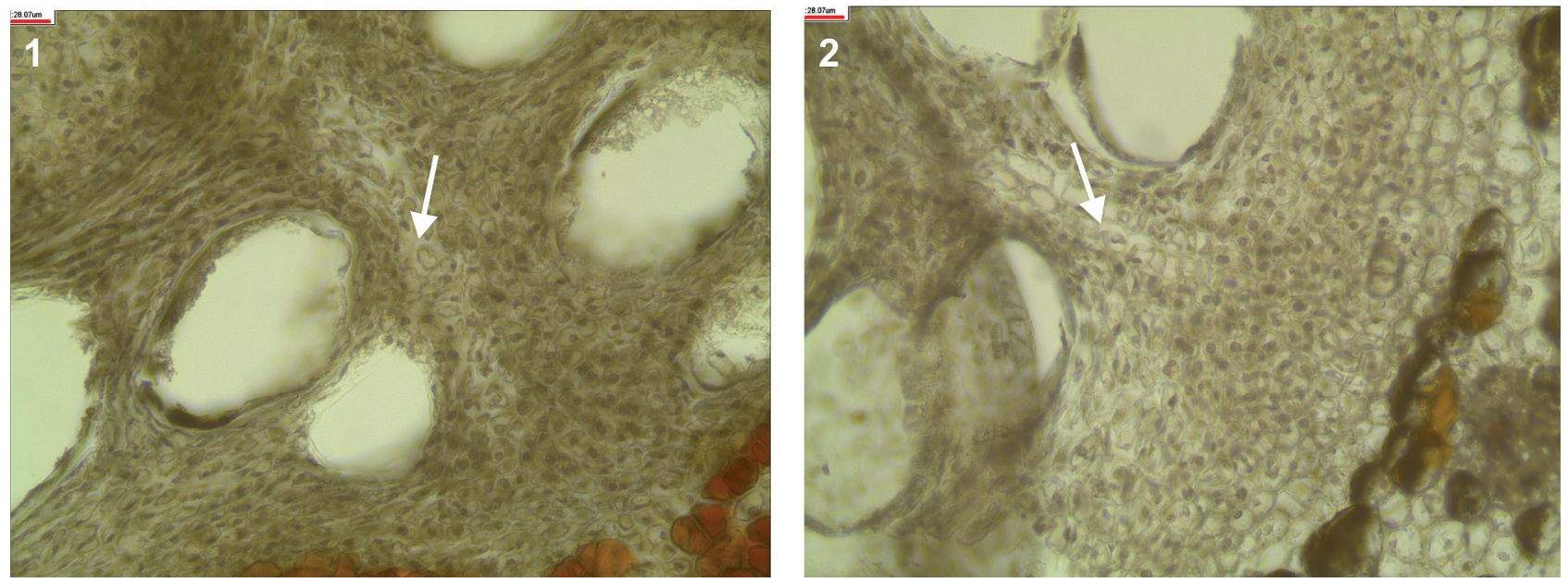

Fig. 4. LM. A fragment from the transverse section of the endocarp with a strand of cells outlining the germination valve (arrows) in Cornus mas (1) and Cornus officinalis (2)
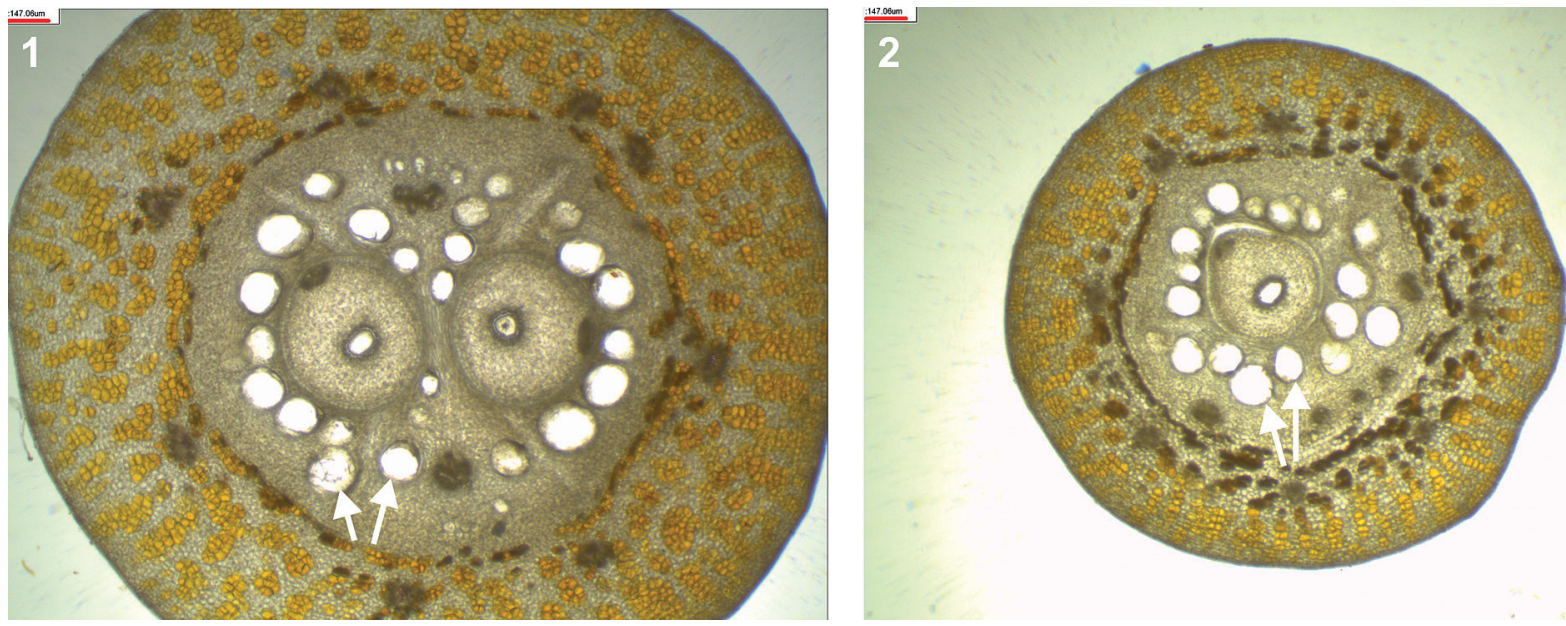

Fig. 5. LM. Resin cavities (arrows) in endocarps of Cornus mas (1) and Cornus officinalis (2)
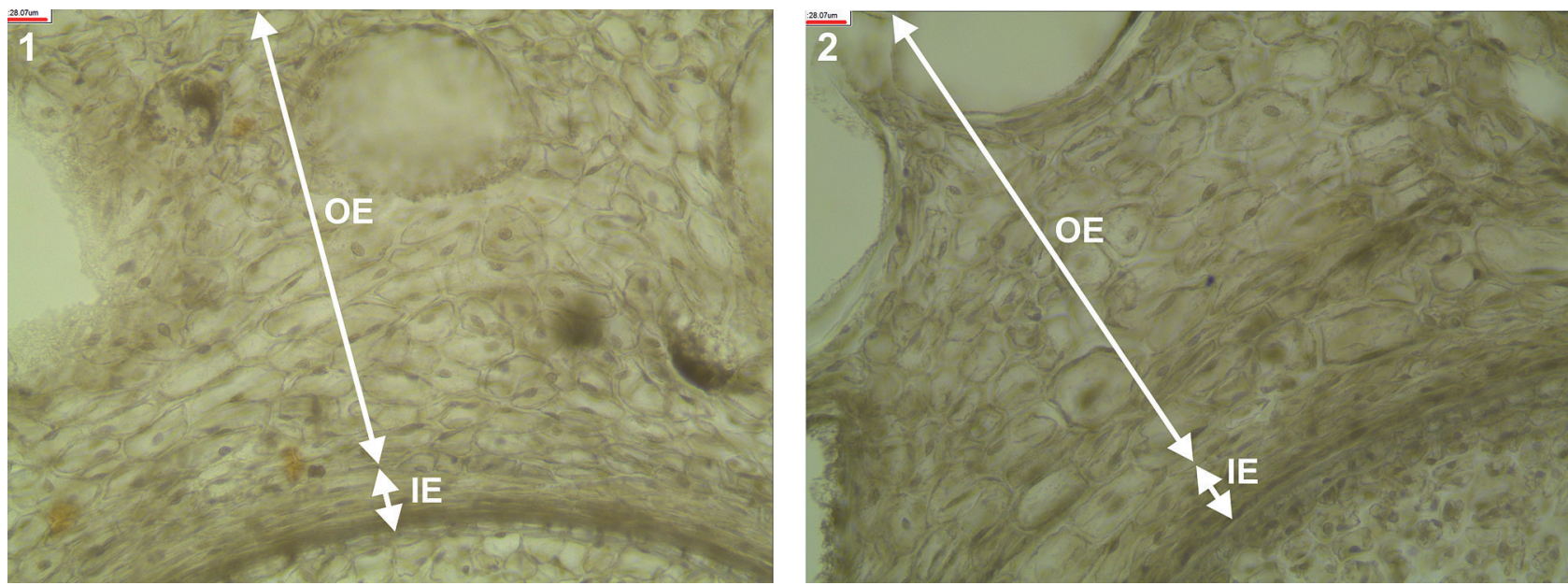

Fig. 6. LM. Sclereids of inner and outer endocarp in Cornus mas (1) and Cornus officinalis (2): IE - inner endocarp, OE outer endocarp 
the circumference of locules (Fig. 6). According to the results reported by KANIEWSKI \& HAUSBRANDT (1968), crystals of calcium oxalate appear in cells arranged outside; however, this was not confirmed in this study. The transverse sections of $C$. mas endocarps encompassing its apex parts (close to the style) showed
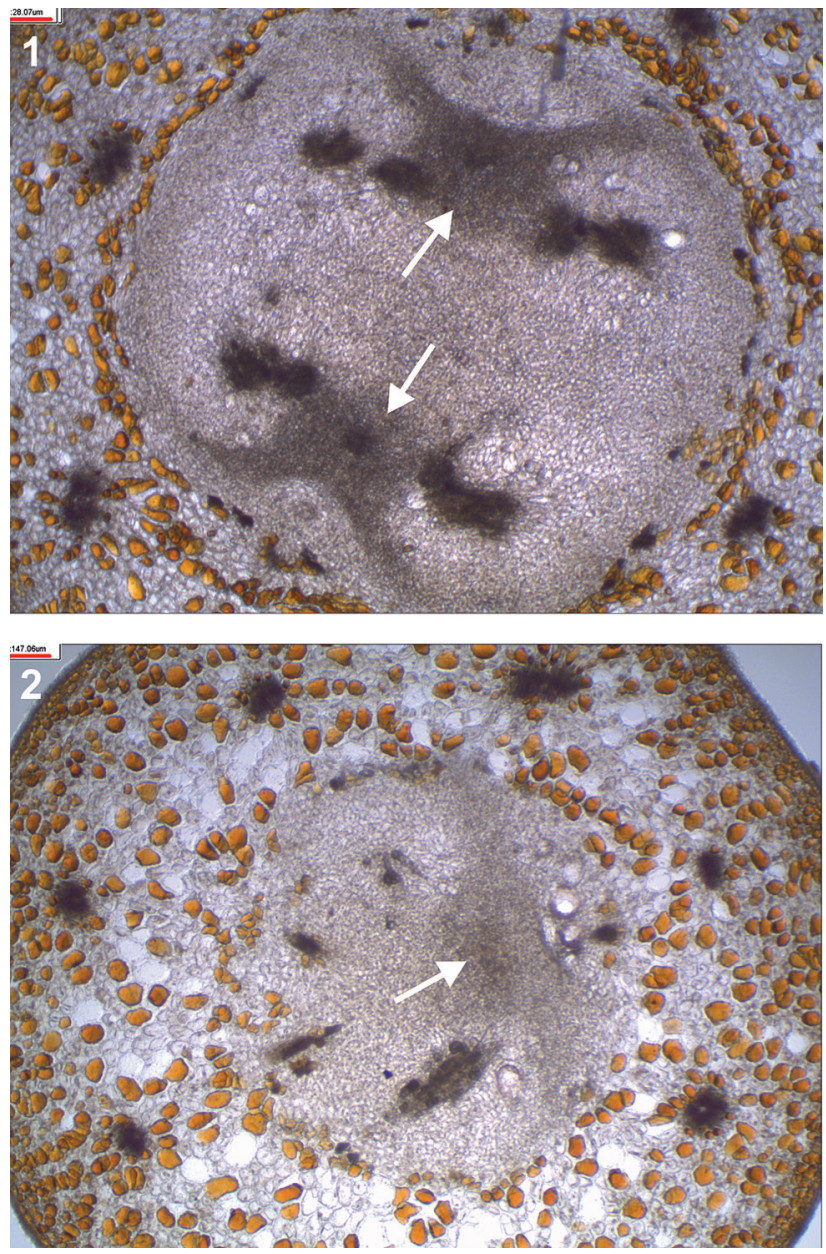

Fig. 7. LM. Transverse sections of Cornus mas (1) and Cornus officinalis (2) fruit stones at the apex: arrows - groups of cells with slightly thickened walls

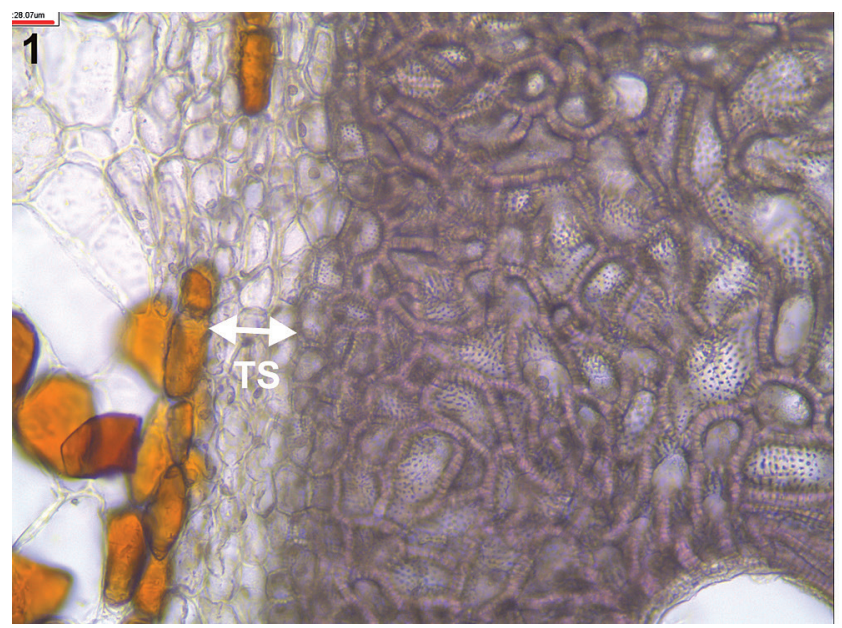

the presence of cells with slightly thickened cell walls, while no such thickening was observed in cells situated close to the base of the endocarp (Figs 7 and 8). Cells distinguishing the germinating valves and the most outer cells of the endocarp, which are directly adjacent to the mesocarp, were smaller in comparison
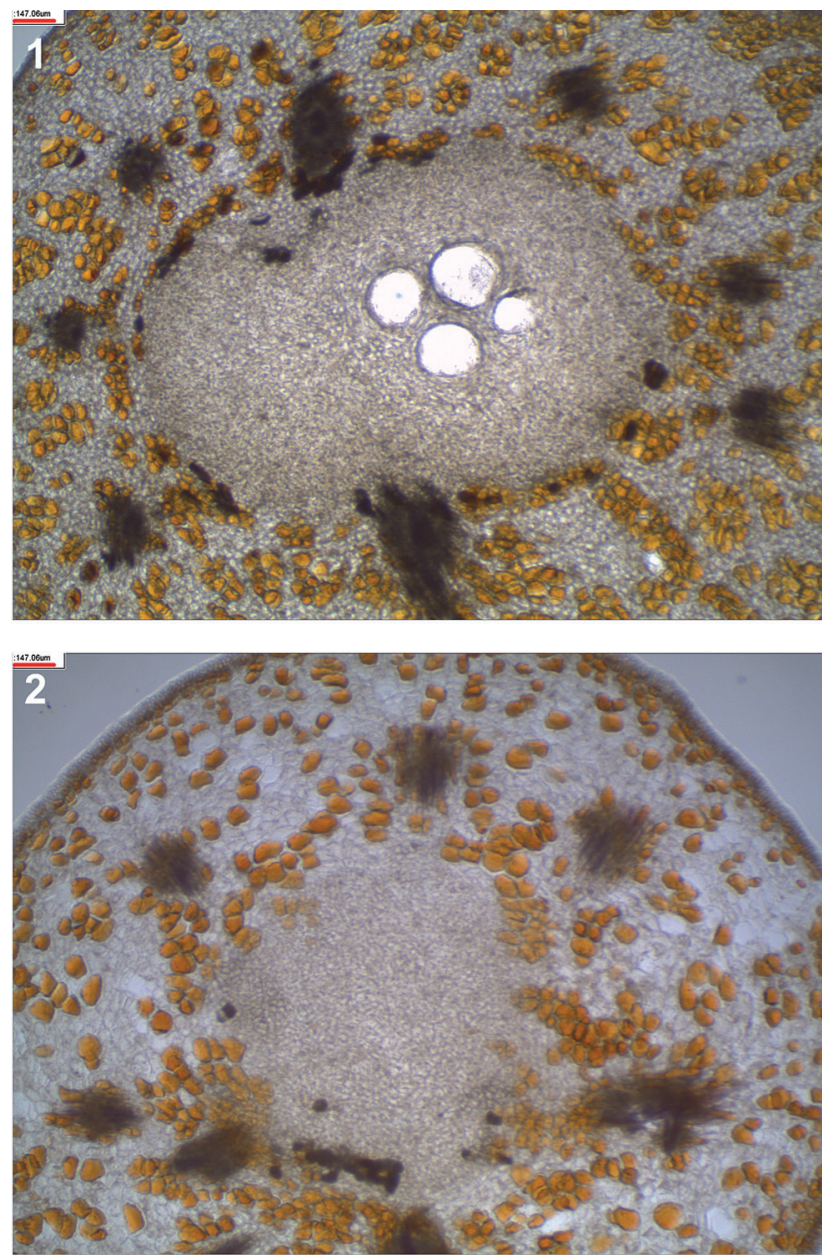

Fig. 8. LM. Transverse sections of Cornus mas (1) and Cornus officinalis (2) fruit stones at the base

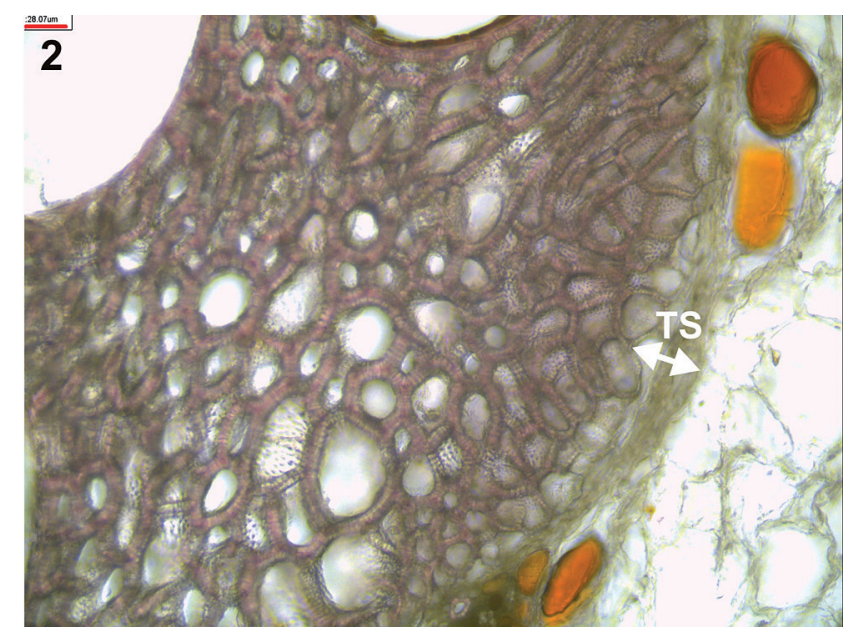

Fig. 9. LM. Circular strand (transition sclereids - TS) on the outer margin of the endocarp of Cornus mas (1) and Cornus officinalis (2) 
with other endocarp cells. According to KANIEWSKI \& HAUSBRANDT (1968), at the very early stage of fruit formation, still in the ovary, a band of two to three layers of cells was observed at the boundary of the mesocarp and the future endocarp, separating these two layers, which the above-mentioned authors called the circular strand. MorozowsKa et al. (2013) also described the presence of two to five layers of cells, forming the so-called transition sclereid zone located on the outer margin of an endocarp. The present work confirmed these results both at the early and at the late phases of the drupe development, with the presence of one to two/four layers of cells with only slightly thickened cell walls on the outer margin of the endocarp (Fig. 9). At the end of May, but generally in the first days of June (7.06.11), in cells of the internal endocarp the thickening of cell walls as well as the first symptoms of their lignification were observed. Cells surrounding the resin cavities present in the outer endocarp were at that time also characterized by delicately lignified cell walls (Fig. 10). The described direction of cell wall thickening overtaking their lignification is in agreement with the results of other authors describing drupe development (KANIEWSKI 1963, KanIEWSKI \& HAUSBRANDT 1968).
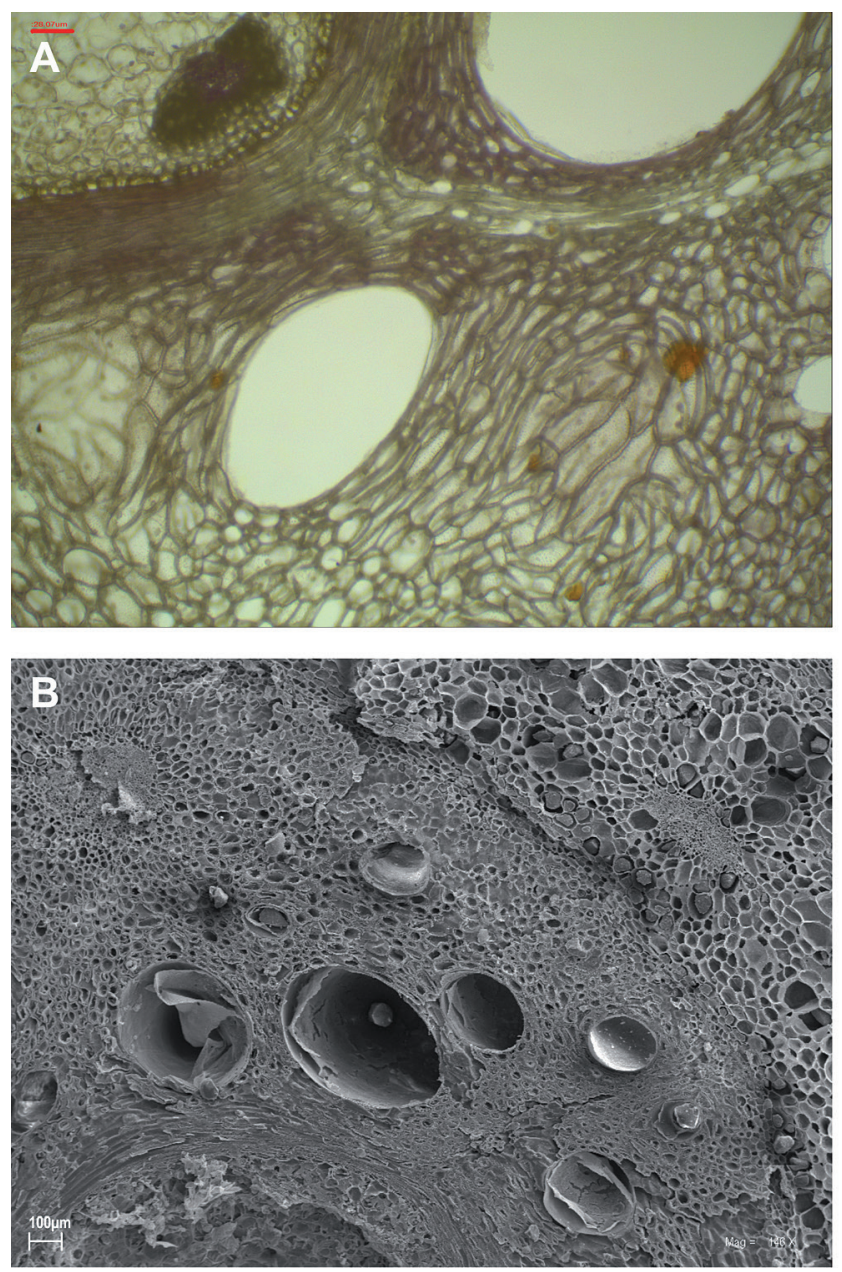

Changes in the anatomical structure of C. mas endocarps observed during the next two weeks (21.06.11), i.e. in the 2 nd phase of fruit development, concerned further cell wall thickening and their lignification. Lignification started in elongated sclereids of the inner endocarp, surrounding the locule cavities. In the outer endocarp lignification was observed first in its outer parts and a little later in cells of its inside part. Less lignified cells were observed between the resin cavities in the middle part of an endocarp. The strands of cells distinguishing the germination valves were characterised by non-lignified cell walls and the thickening of their walls proceeded from the inner to the outer parts of the endocarp (Fig. 11). At the same time one to three layers of smaller and rather thin-walled non-lignified cells were still present on the outer margin of endocarp and in the lignified cells of the endocarp the presence of numerous pits was observed (Fig. 12). Transverse sections of endocarps at the same time of development showed the presence of cells with thickened and lignified cell walls both in the upper and bottom parts of the endocarp (Figs 13 and 14). At the same time, in C. officinalis endocarps, only the very first symptoms of cell wall thickening and ligni-
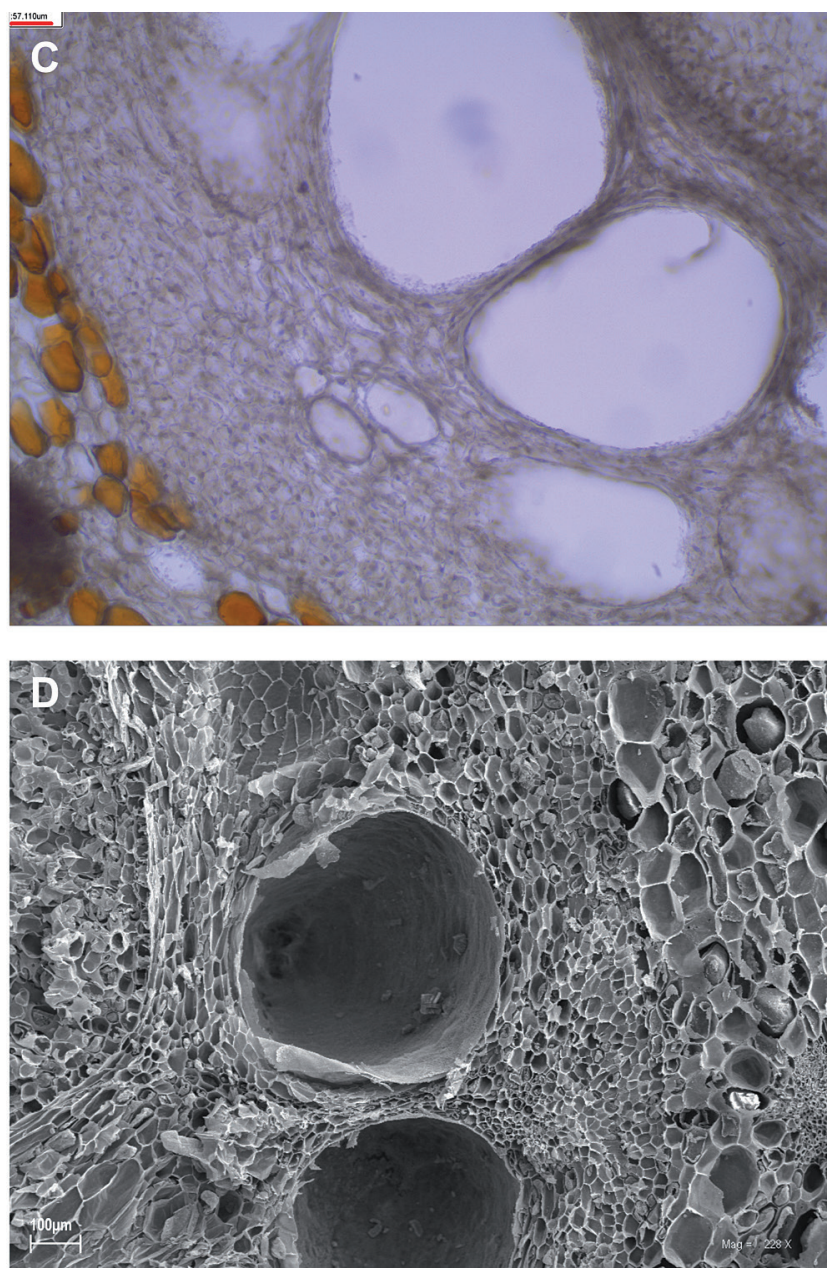

Fig. 10. Lignification of endocarp cell walls surrounding resin cavities in Cornus mas: A - LM, B - SEM and Cornus officinalis: C - LM, D - SEM 
fication were present, but it was already possible to observe, similarly as in C. mas endocarps, the presence of non-lignified cells distinguishing the germination valve and cells forming the surface layer of an outer endocarp directly adjacent to the mesocarp

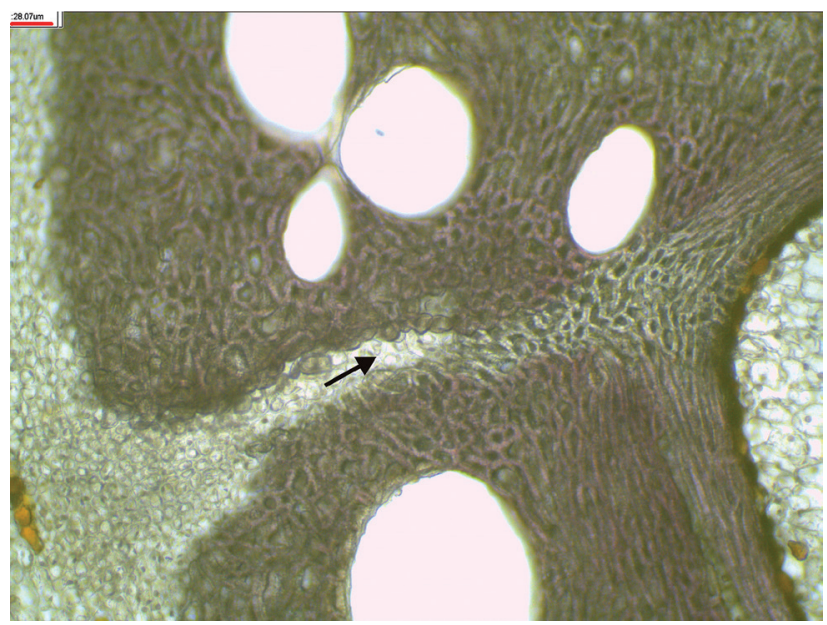

Fig. 11. LM. The strand of cells distinguishing the germination valve (arrow) with partly thickened cell walls in Cornus mas

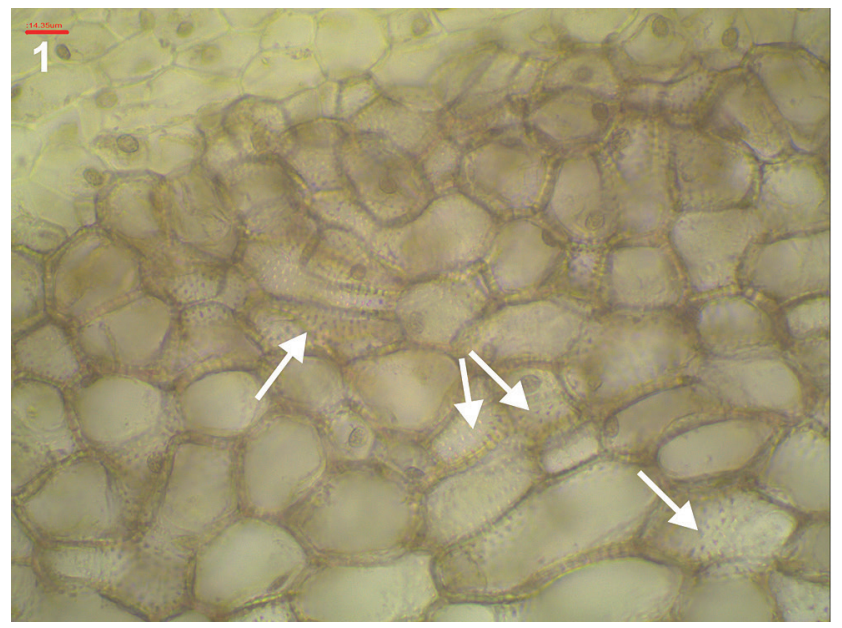

(Fig. 15). In the transverse sections of apex parts of C. officinalis endocarps smaller cells with little thickened and lignified walls, in comparison with the other cells in the endocarp, were observed (Fig. 16). That means that for both examined species the thickening and further lignification process of endocarp cells starts in its upper part, close to the style. The described sequence of the C. mas endocarp development is generally in agreement with the earlier results of KANIEWSKI \& HaUsBRANDT (1968). Some differences concerned the time of lignification of cells forming the strands distinguishing the germinating valves, which according to our observations were still not lignified at the beginning of July, while according to the above mentioned authors the whole endocarp was lignified already at the end of June (Fig. 17). Such a difference may be partly a result of different weather conditions during the years of particular observations.

Observations of the transverse and longitudinal sections of endocarps made during later stages of their development, for both examined species, confirmed further cell wall thickening and lignification

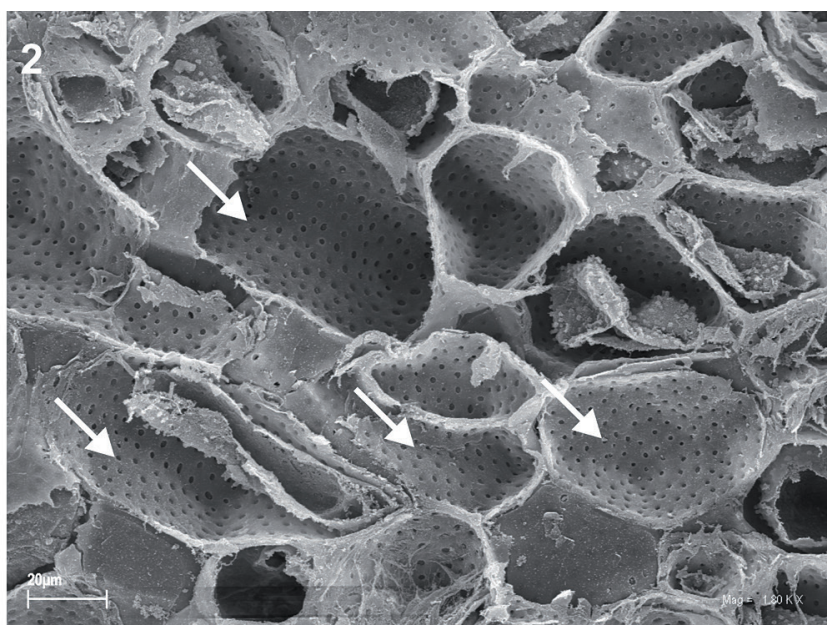

Fig. 12. Pits (arrows) in lignified cell walls of the endocarp in Cornus mas: 1 - LM, 2 - SEM

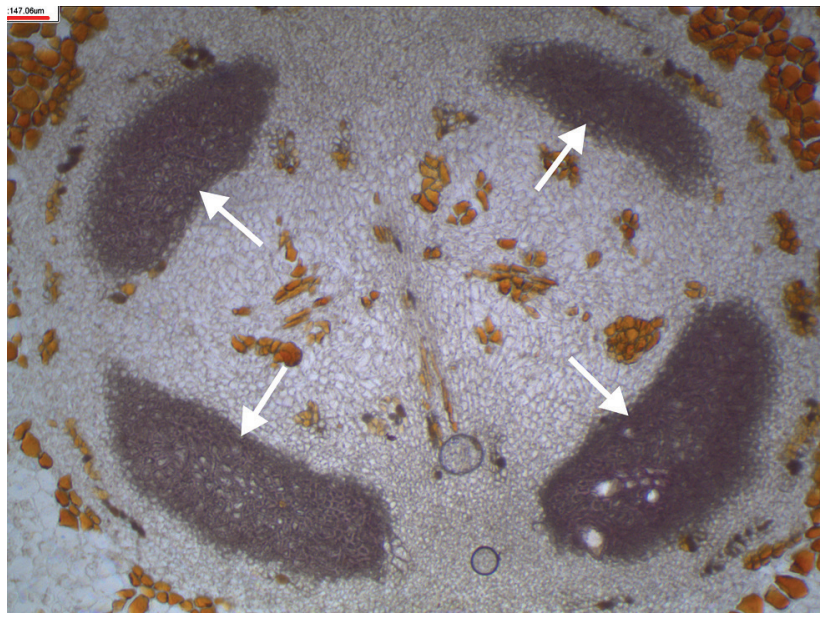

Fig. 13. LM. Thickened and lignified endocarp cells (arrows) close to the apex of the fruit stone in Cornus mas

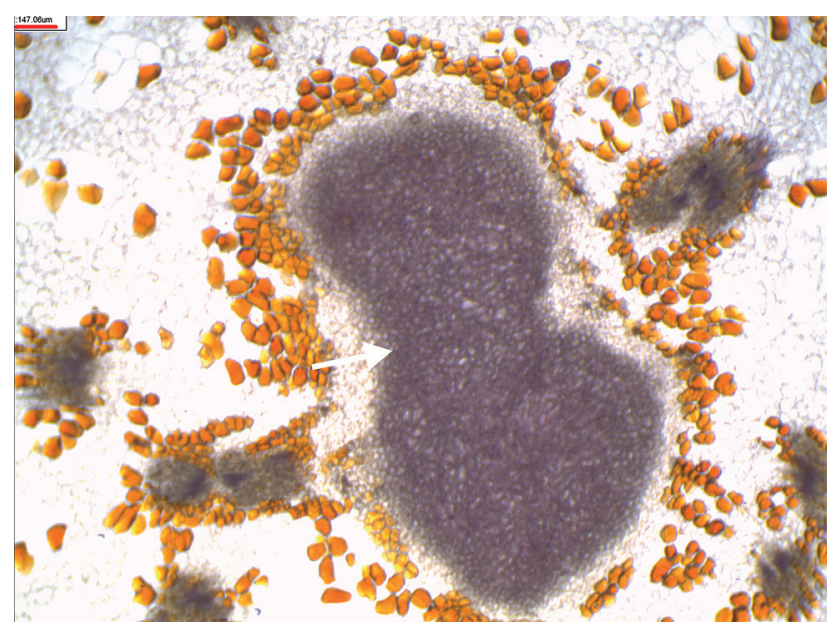

Fig. 14. LM. Thickened and lignified endocarp cells (arrows) close to the base of the fruit stone in Cornus mas 
in the most outer and the most inner parts of an endocarp, and also in its middle parts almost at the same time (Figs 18 and 19). The lignification process observed in C. officinalis endocarps was delayed for several days in comparison to C. mas endocarps, but

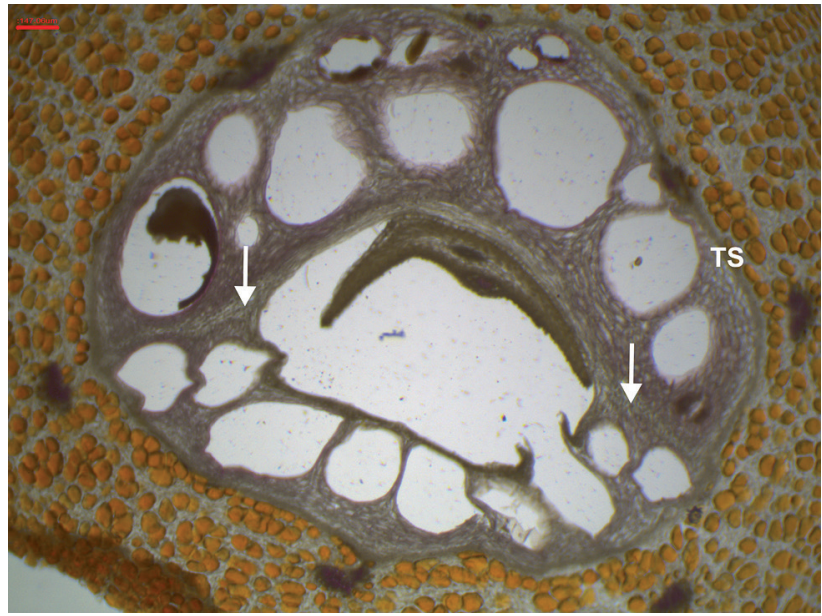

Fig. 15. LM. Transition sclereids (TS) and non-lignified cells distinguishing the germination valve (arrows) in Cornus officinalis
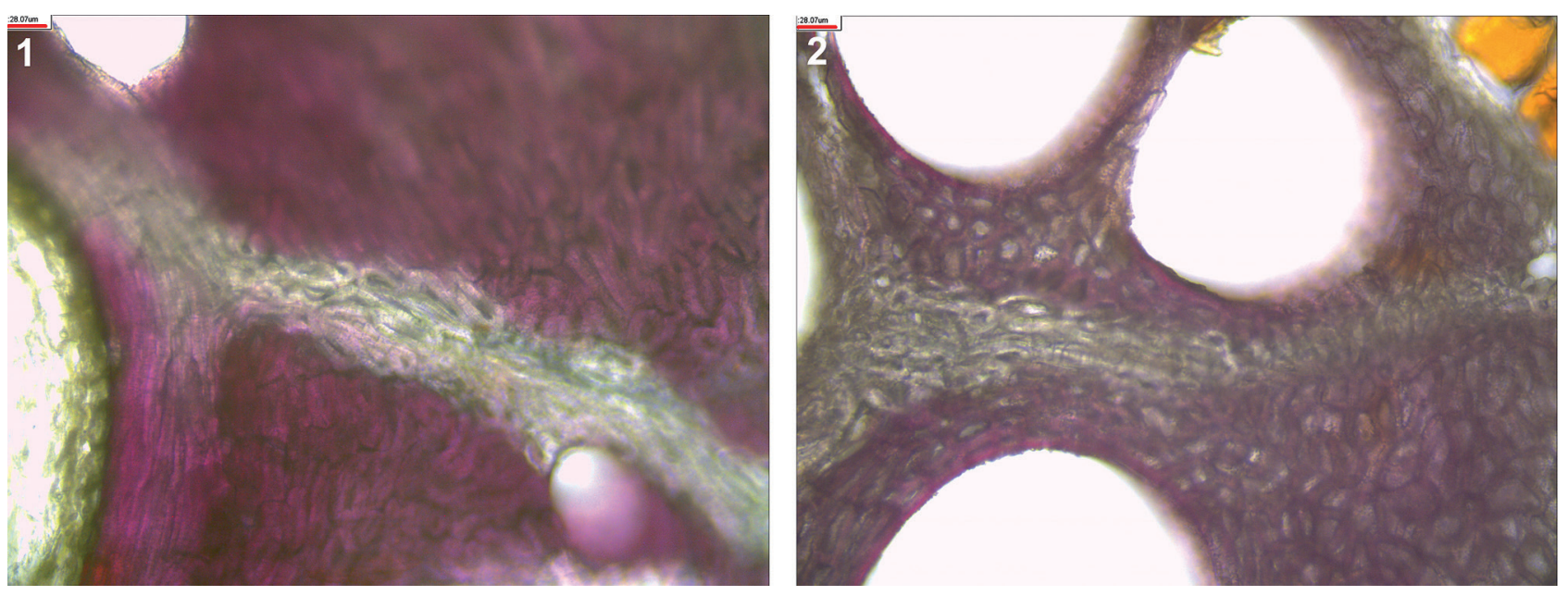

Fig. 17. LM. Non-lignified cells distinguishing the germination valve in endocarps of Cornus mas (1) and Cornus officinalis (2)

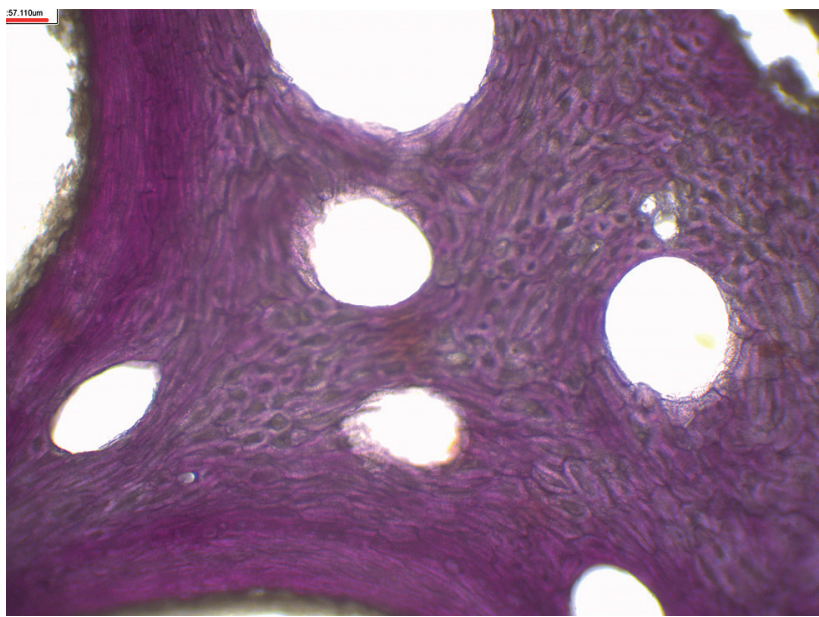

Fig. 18. LM. Thickened and lignified cell walls in the whole endocarp of Cornus mas the scheme of the process was the same. At the final stages of endocarp development the presence of cells with very thickened and lignified cell walls was described in whole endocarps of both examined Cornus species, with an exception of the presence of two-

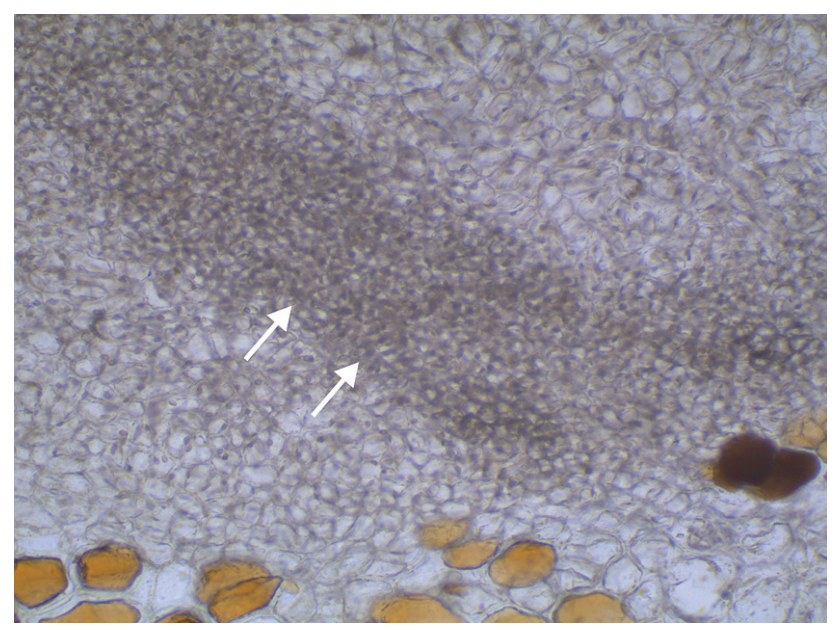

Fig. 16. LM. Transverse section of the upper part of a Cornus officinalis fruit stone with visible thickened cell walls (arrows)
Fig. 19. LM. Thickened and lignified cell walls in the whole endocarp of Cornus officinalis 

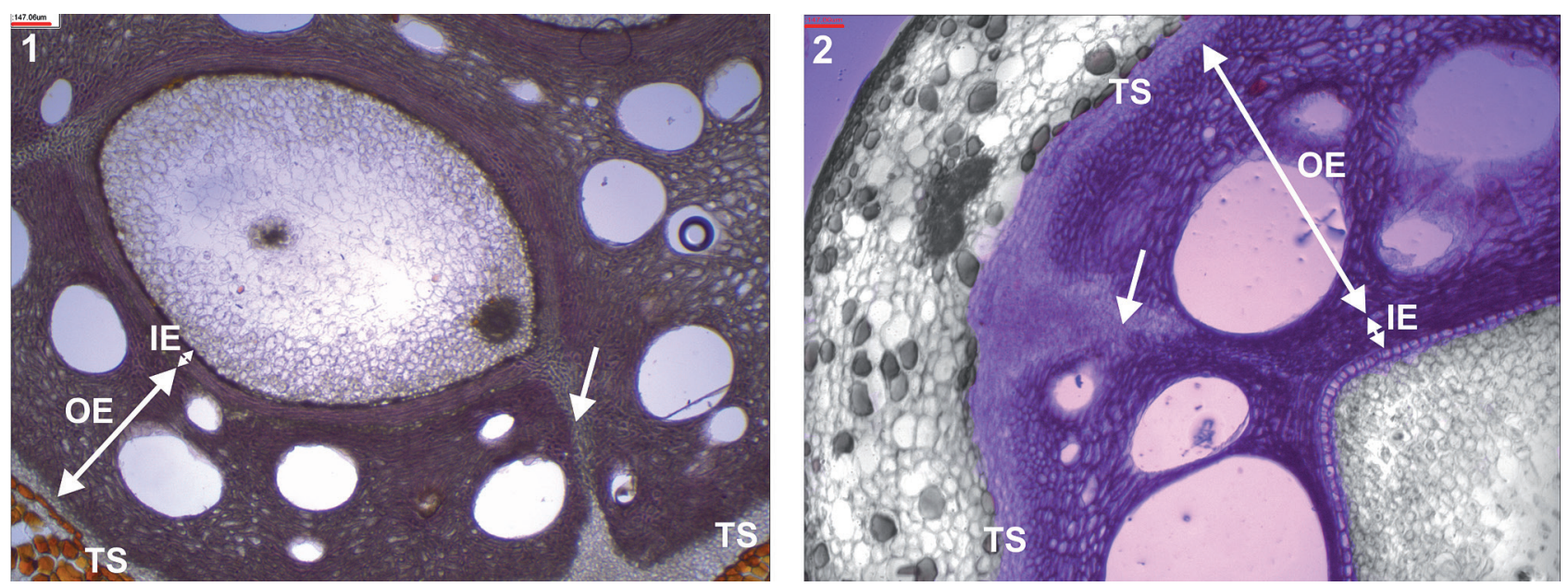

Fig. 20. LM. Ripened endocarps of Cornus mas (1) and Cornus officinalis (2) with slightly lignified transition sclereids (TS), cells distinguishing the germination valves (arrows) and strongly lignified inner (IE) and outer (OE) endocarps

three layers of almost non-lignified cells in the most outer part of the endocarp and much less lignified cells in the strands distinguishing the germinating valves (Fig. 20).

\section{CONCLUSION}

In the process of anatomical development of examined endocarps the formation of two layers, the inner and the outer endocarp, was observed. Changes in the anatomical structure of endocarps concerned a gradual thickening of the cell walls and their lignification. Lignification begins in cells forming the inner endocarp and it proceeds in the outside parts of the outer endocarp, except for several layers of cells on its margin. The cells forming the rest of the outer endocarp lignify almost at the same time. The described process begins in cells of the upper part of the endocarp, and it gradually proceeds to its base. Cell wall thickening in cells distinguishing the germinating valves is delayed by several days in comparison with the other parts of endocarp and their lignification is less intensive. In endocarps of both examined species thickening of the cell walls and their lignification follow the same course, with several days of delay in respect of Cornus officinalis endocarps.

The described process of the development and lignification of C. mas and C. officinalis endocarps corresponds best with the type of fruit development observed for Prunus cerasus (KANIEWsKi 1963).

\section{ACKNOWLEDGEMENTS}

We are grateful to Wojciech Klimko for his assistance with computer data recording. The study was supported by the Department of Botany, Poznań University of Life Sciences.

\section{REFERENCES}

Boynton D., WiLde M.H. (1959): Development of the black raspberry fruit. I. Seasonal increases in gross volume, dimension and dry weight. American Society for Horticultural Science 73: 158-163.

Bugaza W. (2000): Drzewa i krzewy. Państwowe Wydawnictwo Rolnicze i Leśne, Warszawa.

ConNors C.H. (1919): Growth of fruits of the peach. New Jersey Agricultural Experiment Station Annual Report 40: 82-89.

Demir F., Kalyoncu I.H. (2003): Some nutritional, pomological and physical properties of cornelian cherry (Cornus mas L.). Journal of Food Engineering 60(3): 335-341.

Ercisli S., Yilmaz S.O., Gadze J., Dzubur A., HadziaBulic S., Aliman J. (2011): Some fruit characteristics of cornelian cherries (Cornus mas L.). Notulae Botanicae Horti Agrobotanici Cluj-Napoca 39(1): 255-259.

EyDE R.H. (1988): Comprehending Cornus: puzzles and progress in the systematics of the dogwoods. The Botanical Review 54: 233-351.

Fan C., XIANG Q.-Y. (2001): Phylogenetic relationships within Cornus (Cornaceae) based on 26S rDNA sequences. American Journal of Botany 88: 1131-1138.

Guzicka M., Zieliński J., Tomaszewski D., Gawlak M. (2012): Anatomical study on the developing pericarp of selected Rosa species (Rosaceae). Dendrobiology, 68: 77-87.

KANIEWSKI K. (1963): Badania porównawcze nad rozwojem endokarpu różnych gatunków roślin wytwarzających owoce pestkowe. Rocznik Dendrologiczny 17: 5-45.

KanieWSKI K., Hausbrandt L. (1968): Badania porównawcze nad rozwojem owocni kilku gatunków rodzaju Cornus. Rocznik Dendrologiczny 22: 73-90. 
Kucharska A.Z., Szumny A., SoKÓŁ-ŁętowsKa A., ZAJĄC K. (2009): Fatty acid compositions of seed oils of cornelian cherry (Cornus mas L.). Acta Biochimica Polonica 56, Suppl. 2: 21-22.

Ma W., Wang K-J., Cheng C-S., Yan G-Q., Lu W-L., Ge J-F., Cheng Y-X., LI N. (2014): Bioactive compounds from Cornus officinalis fruits and their effects on diabetic nephropathy. Journal of Ethnopharmacology 153, 3: 840-845.

MACBRIDE J.F. (1929): Cornus, a genus new to South America. Trop Woods 19: 4-5.

Mirek Z., PięKoś-Mirkowa H., Zając A., Zając M. (2002): Flowering plants and pteridophytes of Poland. A checklist. W. Szafer Institute of Botany, Polish Academy of Sciences, Kraków.

Morozowska M., Gawrońska B., WoźNicka A. (2013): Morphological, anatomical and genetic differentiation of Cornus mas, Cornus officinalis and their interspecific hybrid. Dendrobiology 70: 45-57.

Pantelidis G.E., Vasilakakis M., Manganaris G.A., DiaMANTIDIS G. (2007): Antioxidant capacity, phenol, anthocyanin and ascorbic acid contents in raspberries, blackberries, red currants, gooseberries and cornelian cherries. Food Chemistry 102(3): 777-783.

Pawlowska A.M., Camangi F., Braca A. (2010): Quali-quantitative analysis of flavonoids of Cornus mas L. (Cornaceae) fruits. Food Chemistry 119(3): 1257-1261.

Reeve R.M. (1954a): Fruit histogenesis in Rubus strigosus. I. Outer epidermis, parenchyma, and receptacle. American Journal of Botany 41: 152-160.

Reeve R.M. (1954b): Fruit histogenesis in Rubus strigosus. II. Endocarp tissues. American Journal of Botany 41: 173-181.

RutKowski L. (2006): Klucz do oznaczania roślin naczyniowych Polski niżowej. Wydawnictwo Naukowe PWN, Warszawa.

Seneta W., Dolatowski J. (2009): Dendrologia. Wydawnictwo Naukowe PWN, Warszawa.

SterLING C. (1953): Developmental anatomy of the fruit of Prunus domestica L. Bulletin of the Torrey Botanical Club 80: 457-477.

Stevens P.F. (2012): Angiosperm Phylogeny Website. Version 12, July 2012 [and more or less continuously updated since]. http://www. mobot.org/ MOBOT/research/APweb/ [access: 15.04.2015].

Tukey H.B. (1935): Growth of the embryo, seed and pericarp of the sour cherry (Prunus cerasus) in re- lation to season of fruit ripening. Proceeding of the American Society for Horticultural Science 31: 125-144.

Tukey H.B., Young J.O. (1939): Histological study of the developing fruit of the sour cherry. Botanical Gazette 100: 723-749.

VidRIH R., ČejIĆ Ž., Hribar J. (2012): Content of certain food components in flesh and stones of the cornelian cherry (Cornus mas L.) genotypes. Croatian Journal of Food Science and Technology 4(1): 64-70.

WANGERIN W.L. (1910): Cornaceae. In: A. Engler (ed.). Das Pflanzenreich, ser. IV, fam. 229 (Heft 41). W. Engelmann, Leipzig.

Xiang Q.-Y., Brunsfeld S.J., Soltis D.E., Soltis P.S. (1996): Phylogenetic relationship in Cornus based on chloroplast DNA restriction sites: implications for biogeography and character evolution. Systematic Botany 21: 515-534.

Xiang Q.-Y., Soltis D.E., Morgan D.R., Soltis P.S. (1993): Phylogenetic relationships of Cornus L. sensu lato and putative relatives inferred from rbcL sequence data. Annals of the Missouri Botanical Garden 80: 723-734.

Xiang Q.-Y., Soltis D.E., Soltis P.S. (1998): Phylogenetic relationships of Cornaceae and close relatives inferred from matK and rbcL sequences. American Journal of Botany 85: 285-297.

Xiang Q.-Y., Thomas D.T., Zhang W., Manchester S.R., Murrell Z. (2006): Species level phylogeny of the genus Cornus (Cornaceae) based on molecular and morphological evidence - implications for taxonomy and Tertiary intercontinental migration. Taxon 55: 9-30.

Zielí́ski J., Guzicka M., Tomaszewski D., MaciejewsKa-RutKowska I. (2010): Pericarp anatomy of wild roses (Rosa L., Rosaceae). Flora 205: 363-369.

ŻuKowski W., JACKowiaK B. (eds) (1995): Lista roślin naczyniowych ginących i zagrożonych na Pomorzu Zachodnim i w Wielkopolsce. In: Ginące i zagrożone rośliny naczyniowe Pomorza Zachodniego i Wielkopolski. Prace Zakładu Taksonomii Roślin UAM w Poznaniu 3: 9-92.

For citation: MoRozowsKa M., WYSAKOWSKA I. (2016): Anatomical study of Cornus mas L. and Cornus officinalis Seib. et Zucc. (Cornaceae) endocarps during their development. Steciana 20(1): 21-32. doi: 10.12657/steciana.020.004 